\title{
The Geography Teaching Material for Senior High School Student's Creative Thinking
}

\author{
Sugeng Widodo ${ }^{1}$, Pargito ${ }^{2}$, Yarmaidi ${ }^{3}$ \\ \{sugeng.widodo@fkip.unila.ac.id ${ }^{1}$ \} \\ Faculty of Teacher Training and Education, Lampung University, Bandar Lampung, Indonesia ${ }^{1,2,3}$
}

\begin{abstract}
Students with creative thinking skills shall be able to solve problems swiftly and properly and able to face various challenges in life. The objectives of this research to produce geography teaching material for grade $\mathrm{X}$ to make students think creatively. This research used stages in a research and development method developed by Dick and Carey. Validation tests to determine teaching material properness were done by Indonesian language expert, teaching material expert, and design expert in small and big test groups. Data were analyzed by using statistical descriptive analysis with percentage. The result showed that the geography teaching material for senior high school students was effective to use in learning by $92 \%$ average effectiveness score. The test results in small group showed average effectiveness by $88 \%$, and students' creative thinking results were $9 \%$ very good, $88 \%$ good, and $13 \%$ enough, with creative thinking skill average score of 75 . The test results in big group showed average effectiveness by $86 \%$, and students' creative thinking results were $15 \%$ very good, $80 \%$ good, and $53 \%$ enough, with creative thinking skill average score of 76 .
\end{abstract}

Keywords: Teaching materials, Dick and Carey model, creative thinking.

\section{Introduction}

Teaching students by using teaching materials that make them think creatively so far have not been yet running properly, because basics of creative thinking is not yet mastered, both in elementary and higher levels. This is in line with Rofi'uddin that student's creative thinking skill is still low in elementary and higher levels [1].

The importance of student's creative thinking skill includes that students shall be able to solve problems swiftly and properly, and they were able to face various challenges in life [2]. The senior high school students are cognitively in a stage to think operationally and formally starting from age 11 years and higher [3]. At those ages, students develop their cognitive ability to think in abstract way. They also think rationally or scientifically to solve a problem.

Types of teaching materials are differentiated into some grouping criteria. According to Koesnandar teaching materials based on their subjects are (a) teaching materials purposively designed to learn such as books, handouts, student's work sheet and module; (b) undersigned teaching materials that are used to for learning such as newspaper clippings, newspaper, movies, advertisements and news [4]. Based on this, teaching materials can be divided into written (i.e. books) and unwritten ones (i.e. movies).

The analysis result done by Cahyaningtyas [5] to geography teaching materials for grade $\mathrm{X}$ of senior high school showed that there were 153 errors in punctuation marks, 104 vocabulary mistakes, 161 sentence mistakes, 21 paragraph mistakes, 60 concrete concept mistakes, and 10 
defined concept mistakes. This indicates that there were many mistakes in the teaching materials so that students were difficult to think creatively and this teaching materials needed an immediate betterment. The less clear concept in the first semester of grade $\mathrm{X}$ senior high school text book that makes students are not yet able to think creatively is described as follows:

Utility value concept; the utility value of phenomena on earth is relative, not the same for all people or some particular group of people. A sloping sandy coastal area with clear water is not necessarily having utility value for local inhabitants. This is because the local inhabitants are oriented to use resources on land. Oppositely, for urban people who live in prosperity and in dense area, coastal area would have a high utility value for recreation and tourism [6].

This is an abstract concept with unclear definition. Each student would interpret the information provided in this concept differently. This condition makes incomplete concept understanding and students would have difficulties to understand that finally causes reluctantness $t$ learn and less creative thinking. The concept should be defined clearly with a clear example.

The objectives of this research to produce geography teaching material for grade $\mathrm{X}$ to make students think creatively.

\section{Research Method}

This research used procedural model to describe the plot to produce geography teaching materials for grade $\mathrm{X}$ to make students think creatively [7].

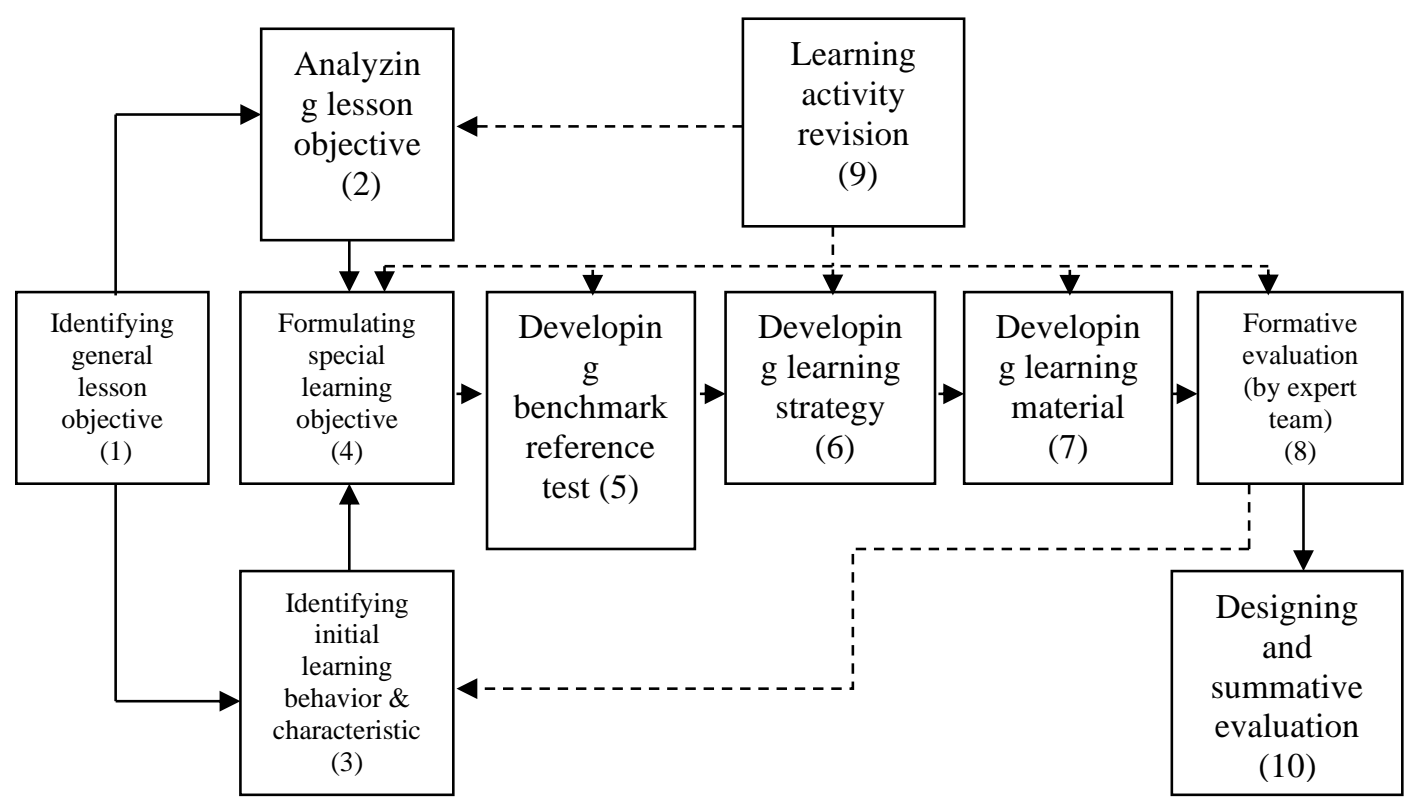

Fig. 1. Dick and Carey model development design [7]

Subjects to test this research and development products were: 1) expert teams containing of field study expert, linguists, and design expert; 2) small group containing of 6 students from NU Islamic Senior High School in Tanjungkarang of Bandar Lampung. These activities were to obtain responses of the substances, to determine properness from language and presentation 
aspects, and to identify problems in understanding teaching material. The small group test was conducted in January 2020; 3) big group test in Public Senior High School 5 with 32 students.

Instruments to collect data in this research were: 1) questionnaires given to experts, and then experts' inputs were made for basics to revise teaching material product; 2) questionnaires to assess product acceptance by teachers and students; 3) essay problems to find out students' thinking skill abilities.

Data were analyzed by using percentage statistical descriptive analysis. This analysis processes data from field test; the questionnaires and essay problems (to measure creative thinking ability). Questionnaire data were processed by using Likert scale criteria. Percentage of each subject answer is estimated by using the following formula:

$$
\text { Percentage }=\frac{\sum \text { Total score of questionnaire answer }}{\mathrm{n} \times \text { highest score } \times \text { total students }} \times 100 \%
$$

$n=$ number of problems

The following setting is used to interpret and to make decision.

Table 1. measure creative thinking ability

\begin{tabular}{cll}
\hline Accomplishment level (\%) & qualification & description \\
\hline $86-100$ & Very efficient & Not revised \\
$71-85$ & Efficient & Not revised \\
$56-70$ & Efficient enough & Revised \\
$0-55$ & Less efficient & Revised \\
\hline
\end{tabular}

The following formula is used for estimation and criteria to interpret student's creative thinking ability data:

$$
\text { Creative Score }=\frac{\text { Score obtained by Student }}{\text { Maximum score }} \times 100 \%
$$

Creative thinking ability is differentiated into three criteria: 81 - 100 (very good), $61-80$ (good), 41- 60 (enough), 21-40 (poor), and 0 - 21 (very poor) [9].

\section{Research Result and Development}

\subsection{Validation of Geography Substance}

The assessment result by geography substance expert is presented in Figure 1 below. 


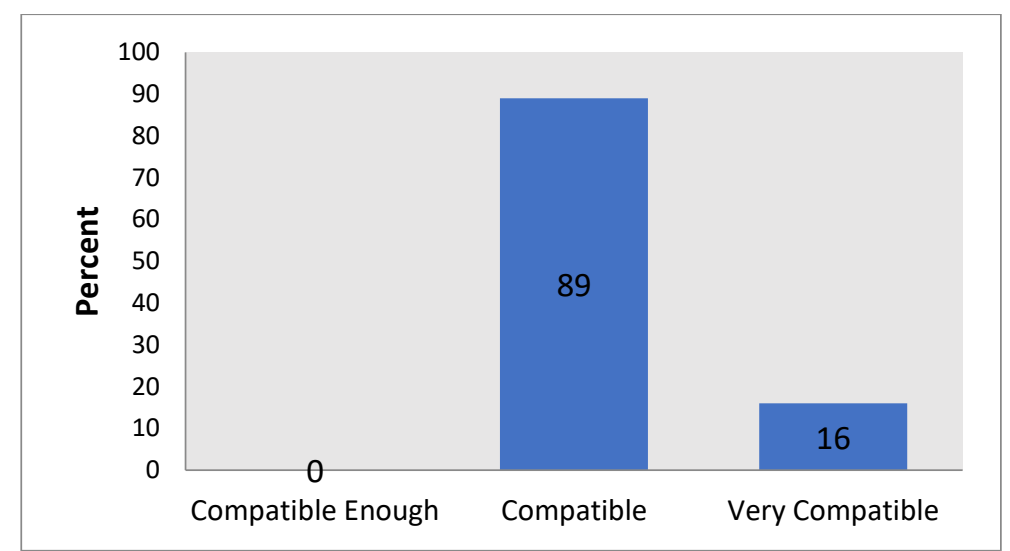

Fig. 1. The assessment of geography teaching material as result of development product by geography content/substance expert

Assessment result by teaching material expert (Figure 1) shows that $11 \%$ geography teaching material as result of development is very compatible and $89 \%$ is compatible. Total assessment score is $4.1(82 \%)$ from 1 to 5 scale, so that the teaching material is proper and efficient to use for learning with efficient category.

\subsection{Indonesia Language Validation}

The validation result of Indonesia language is presented in Figure 2 below.

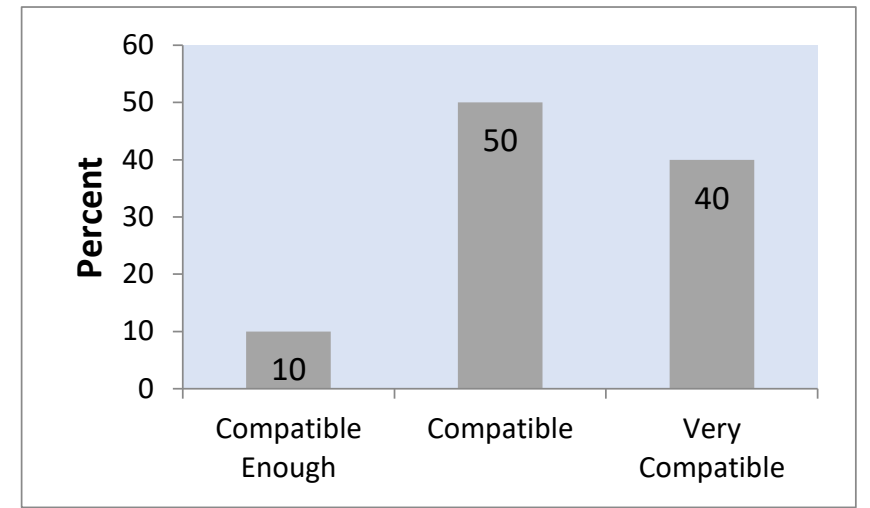

Fig. 2. The Indonesia language assessment of geography teaching material as result of development product by Indonesia linguist

Assessment result by Indonesia linguist expert (Figure 2) shows that $40 \%$ geography teaching material as result of development is very compatible and $50 \%$ is compatible. Assessment score by Indonesia linguist is $4.1(82 \%)$ from 1 to 5 scale, and it indicates that the geography teaching material is proper and efficient to use for learning with efficient category.

\subsection{Design Validation}

The assessment result by design expert is presented in Figure 3 below. 


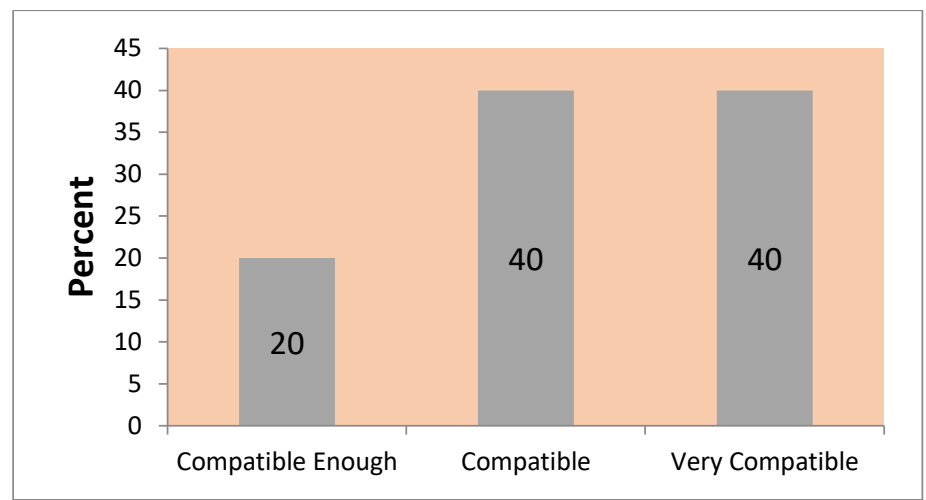

Fig. 3. The assessment result of geography teaching material as result of development product by design expert

The design expert assessment results (Figure 3) are that the geography teaching materials are $40 \%$ very compatible, $40 \%$ compatible, and $20 \%$ compatible enough. Total score is 4.0 $(80 \%)$ from 1 to 5 scale. This result indicates that the geography teaching material is proper and efficient to use for learning with efficient category.

\subsection{Testing Result in Small Group}

Data of testing result of the teaching materials in small group are presented in Table 2 below.

Table 2. Students' responses to the critical thinking-oriented geography teaching materials to test in a small group.

\begin{tabular}{|c|c|c|c|c|c|c|c|c|c|}
\hline \multirow{2}{*}{ No } & \multirow{2}{*}{ Item } & \multicolumn{8}{|c|}{ Score } \\
\hline & & 2 & $\%$ & 3 & $\%$ & 4 & $\%$ & 5 & $\%$ \\
\hline 1 & Cover/layout attractiveness & & & 3 & 20 & 6 & 40 & 6 & 40 \\
\hline 2 & Procedure sequence order in each chapter & & & & & 8 & 53.3 & 7 & 46.7 \\
\hline 3 & Inter-chapters procedure sequence order & & & & & 9 & 60.0 & 6 & 40 \\
\hline 4 & Concept understanding easiness & & & & & 7 & 46.7 & 8 & 53.3 \\
\hline 5 & Easiness in finding concept application & & & & & 8 & 53.3 & 7 & 46.7 \\
\hline 6 & Easiness in answering questions & & & & & 10 & 66.7 & 5 & 33.3 \\
\hline 7 & Easiness in finding questions & & & & & 6 & 40.0 & 9 & 60.0 \\
\hline 8 & Very attractive figures & & & 4 & 26.7 & 5 & 33.3 & 6 & 40 \\
\hline
\end{tabular}

Descriptions 1 = improper, 2 = less proper, 3 = proper enough, 4 = proper, $5=$ very proper

Table 2 shows that students' responses on cover/layout attractiveness are $40 \%$ very proper and $40 \%$ proper. Students' responses on easiness in answering questions to think creatively are $33.3 \%$ very proper and $66.7 \%$ proper. In general, students' responses upon 8 questions that the researcher asked, they said $48.3 \%$ proper and $39.4 \%$ very proper. Table 4.7 shows that total score students' responses to the geography teaching material in small group test is $83.2 \%$ 
(obtained score 811 divided by maximum score 975 ). This indicates that the geography teaching material is proper and efficient to use for learning with efficient category.

\subsection{Testing Result in Big Group}

Data of creative thinking were collected from essay problem instrument of creative thinking-oriented geography teaching materials for grade X. Creative thinking data are comprised of think fluently, flexible thinking, detailed thinking, and thinking to find out new ideas [10].

Creative thinking can be elaborated into 4 indicators; (1) fluency (an ability to produce many ideas), (2) flexibility (an ability to produce various ideas), (3) originality (an ability to produce new ideas or ideas that never been before), and (4) elaboration (an ability to develop or add ideas to produce detailed ideas). These 4 indicators data are presented in Table 3 below.

Table 3. Percentage of creative thinking indicators of students in Public Senior High School 5 in Bandar Lampung.

\begin{tabular}{ccccccc}
\hline Score & Fluency & Flexi-bility & Origi-nality & Elabo-ration & $\boldsymbol{\Sigma}$ & $\boldsymbol{\%}$ \\
\hline 4 & 45 & 10 & 0 & 25 & 80 & 19.6 \\
3 & 54 & 83 & 39 & 64 & 240 & 58.8 \\
2 & 3 & 8 & 60 & 11 & 82 & 20.1 \\
1 & 0 & 1 & 3 & 2 & 6 & 1.5 \\
$\Sigma$ & 102 & 102 & 102 & 102 & 408 & 100 \\
\hline
\end{tabular}

Description: Score $4=$ very creative, $3=$ creative, $2=$ creative enough, $1=$ not creative.

Table 3 describes obtained percentage of creative thinking indicators of students in Public Senior High School 5 in Bandar Lampung. There were 34 students and each of them did 3 problems (chapter I: one problem, chapter II: one problem, and chapter III: one problem). Each problem had 4 indicators, and each indicator had score 1 to 4 , so that there were 408 items (34 students $\mathrm{x} 3$ problems $\mathrm{x} 4$ indicators).

Percentages of creative thinking indicator distribution (Table 2) show that $58.8 \%$ students got score 3 (creative). Flexibility shows the highest score by 83, meaning that students could answer questions more flexible and freer. Students are able to develop their own alternative answers to the problems given. The lowest score is originality indicator, where students find difficulties in finding new ideas. This is because they are still in practicing stage, seldom getting guidance and trained to think to find new ideas. It accordance with the opinion of Ferede, that student are curently not being guided to think creatively Teachers so far have been training students concerning memorizing, history, and calculating [11]. Fluency indicator shows that students are fluent to answer problems given to them. They are able to express many vocabularies related to the given problems. In elaboration indicator students are able to answer the given problems in detail.

\section{Discussion and Recommendation}

\subsection{Product Superiority}

a. The geography teaching materials were validated by expert team consisting of design expert, geography expert, and linguist of Indonesian language.

b. The geography teaching materials had been tested to small and big groups. 
c. The geography teaching materials emphasize student's creative thinking and support scientific method.

d. Problems related to creative thinking are more contextual with clear figures.

\subsection{Product Weaknesses}

a. The geography teaching materials do not yet emphasize on proper learning strategy or model to obtain creative thinking.

b. The geography teaching materials are designed for one semester, where ideally these must be designed for two semesters.

c. The geography teaching materials were tested only in Bandar Lampung town.

\section{References}

[1] Rofi'uddin. Model Pendidikan Berpikir Kritis-Kreatif untuk Siswa Sekolah Dasar. 2009. (Online). (http://www.infodiknas.com/model-pendidikan-berpikir-kritis-kreatif-untuk-siswa-sekolah-dasar2/).

[2] Peter, Ebiendele Ebosele. Critical thinking: Essence for teaching mathematics and mathematics problem solving skills. African Journal of Mathematics and Computer Science Research. 2012. 5(3): 39-43.

[3] Piaget, J. Studies in Reflecting Abstraction. Hove, UK: Psychology Press. 2001.

[4] Koesnandar. Pengembangan Bahan Ajar Berbasis Web. 2008. [Online] http://www.teknologipendidikan.

[5] Cahyaningtias, Puput. Analisis teks buku geografi kelas X SMA. Prosiding Hasil Penelitian. Malang: Universitas Negeri Malang. 2012.

[6] Sugiyanto. Mengkaji Ilmu Geografi untuk Kelas X SMA dan MA (Kurikulum 2013). Jilid 1. Jakarta: Plati. 2012.

[7] Dick, W., Carey, L., \& Carey, J.O. The Systematic Design of Instruction. Addison-Wesley: Educational Publisher Inc. 2001.

[8] Sugiyono. Metode Penelitian Kuantitatif, Kualitatif dan R\&D. Bandung: Alfabeta. 2016.

[9] Arikunto, Suharsimi. Prosedur Penelitian Suatu Pendekatan Praktik. PT Asdi Mahasatya, Jakarta. 2007.

[10] Obby, Taufik. Global Citizen Preparation: Enhancing Early Childhood Education Through Indonesian Local Wisdom. Universal Journal of Educational Research. 2020.

[11] Ferede. Comparison Study of Time Token and Numbered Head Together Learning Models to Improve Student Life Skills. International Journal of Research and Innovation in Social Science (IJRISS). 2020. Volume IV, Issue IV. 